\title{
Managing For Mulch
}

\section{Grazing management practices can be key to accumulating mulch - vegetation residue - which is beneficial for decreasing soil erosion, improving water infiltration and increasing forage production on rangelands.}

\author{
By Francisco Molinar, Dee Galt and Jerry Holechek
}

$\mathrm{T}$ he role of mulch or ungrazed vegetation that is allowed to naturally decompose isn't realized by many ranchers and some range mangers. Mulch plays a critical role in soil-water relationships that is often overlooked. This, coupled with current drought conditions in the southwestern United States justifies a consideration of the importance of mulch on rangelands. Several early classic studies (reviewed in this article) reveal the benefits of managing for mulch.

\section{Functions Of Mulch}

Mulch generally refers to the dead vegetative material that covers the surface of the earth. It is also sometimes referred to as plant litter. Mulch can be divided into three classes that include ungrazed mature vegetation residues still attached to the plant (cured herbage), vegetation residues detached from plants covering the soil surface (ground litter), and decomposing residues partially or completely incorporated into the soil (humus).

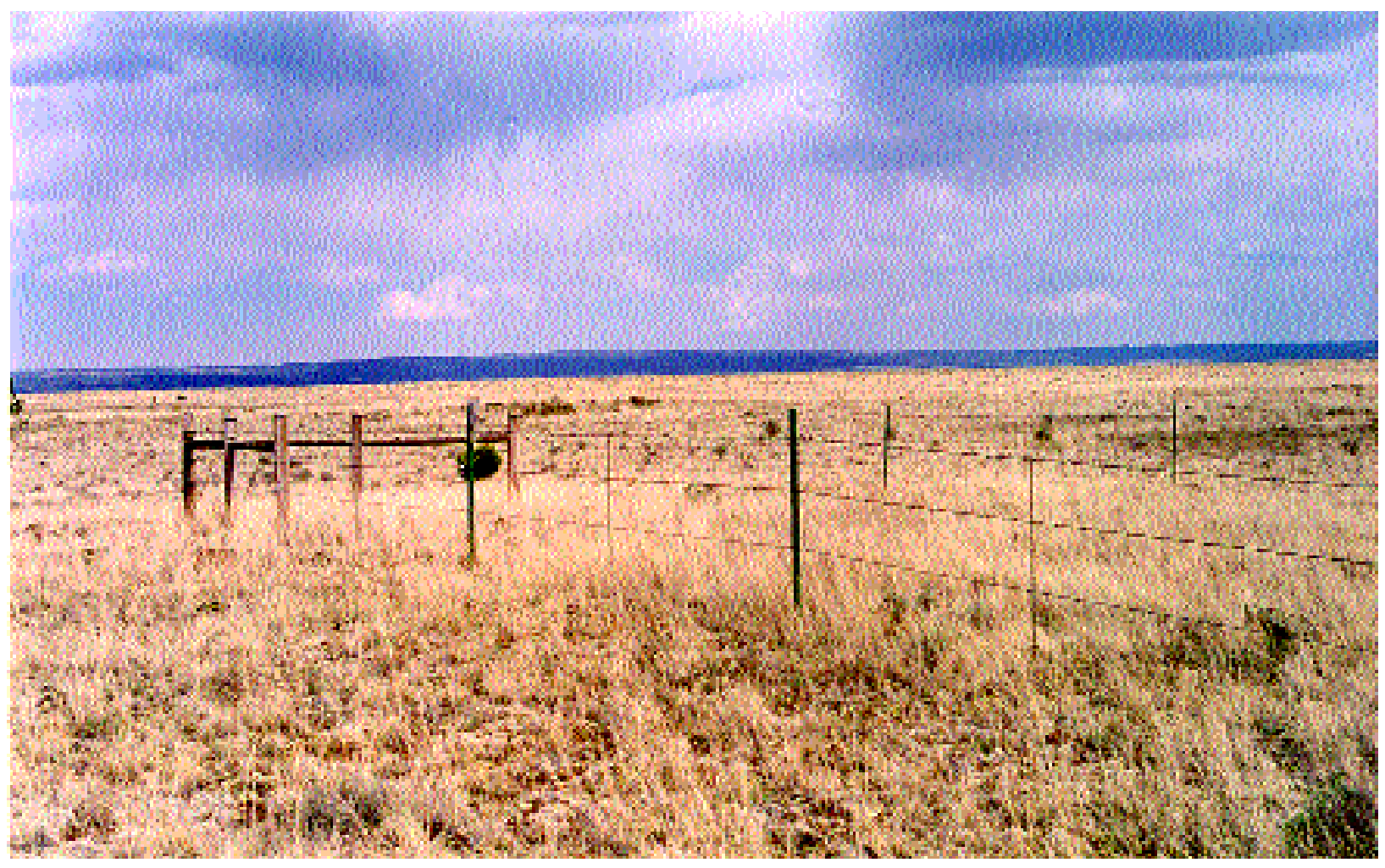

Figure 1. These two pastures in west-central New Mexico are both dominated by blue grama. However the lightly grazed pasture inside the fence produced nearly twice as much forage as the moderately grazed area outside the fence in a dry/year. The higher mulch levels that occurred on the lightly grazed pasture explain in part its higher productivity 
Table 1. Summary of western USA rangeland studies evaluating influences on light, moderate, and heavy stocking rates on moisture infiltration rate (inches/hour) into soil.

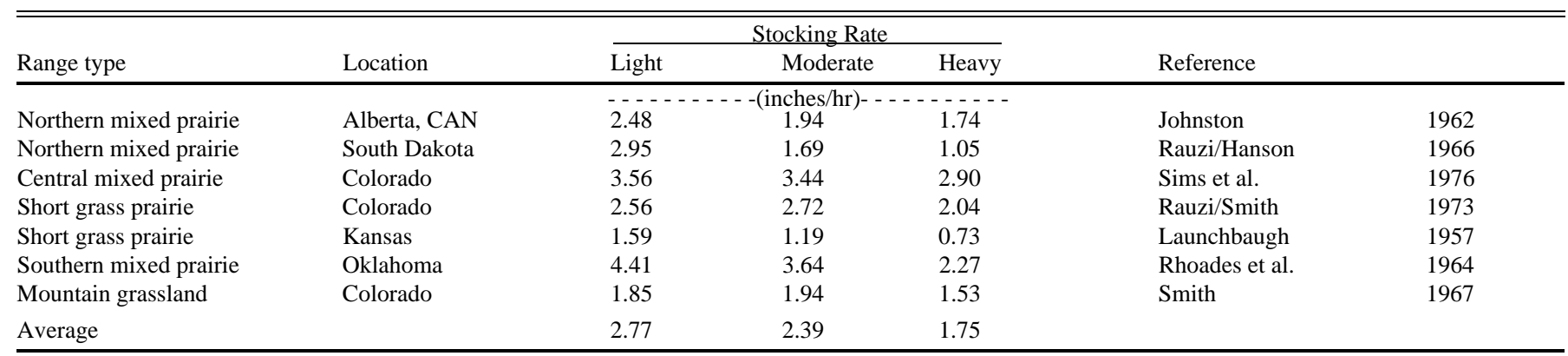

termining soil structure which governs the soil's capability to receive and retain moisture.

Overall, mulch increases the infiltration rate and moisture holding capacity of the soil, reduces rainfall impact, provides a small pool of nutrient for plants, reduces evaporation from the soil, and reduces runoff and erosion. It is the primary factor that range managers can control through manipulation of grazing intensity, timing, and frequency that determines rangeland health.

Several studies are available that have evaluated how different grazing intensities affect both mulch and water infiltration into the soil. These studies are consistent in showing that as grazing intensity is increased and mulch is depleted, water infiltration declines (Table 1). This relationship is quite well demonstrated by a study on heavily grazed, moderately grazed and lightly grazed mixed prairie rangelands in South Dakota (Table 2).

\section{Forage Production And Mulch}

A number of early studies also evaluated the relationship between forage production and mulch. These studies were all consistent in showing that forage production on equivalent sites was closely related to amount of mulch (Beutner and Anderson 1943, Schwan et al. 1949, Rauzi 1960) (Figure 1). Across three locations on North Dakota and Montana mixed prairie rangelands, Rauzi (1960) found that forage production was more than doubled when the amount of mulch left on the site was doubled. This was explained by water intake rates that were twice as high on the well mulched compared to poorly mulched sites.
On mountain rangeland in Colorado, application of light and heavy mulches to heavily grazed rangeland increased forage production $42 \%$ and $50 \%$ over unmulched plots (Schwan et al. 1949). Without mulch, the heavily grazed rangeland produced only about half as much forage as moderately grazed rangeland (550 versus 1,100 lbs/acre). With mulch additions to the heavily grazed rangeland, forage production was about $70 \%$ of the moderately grazed areas (770 versus 1,100 lbs/acre).

On Sonoran Desert rangelands in Arizona, Beutner and Anderson (1943) found that plant debris and litter were nearly as effective as the plants themselves in promoting infiltration and controlling erosion. Ungrazed annual vegetation played an important role in reestablishment of desirable perennial grasses through promoting infiltration. This study indicated that a $20 \%$ increase in infiltration could increase forage production by $50 \%$.

Some of the most thorough investigations of mulch effects on forage production have been conducted on California annual grasslands. Forage production of annual grasses was positively related to level of mulch in these studies (Bentley and Talbot 1951, Bartolome et al. 1980). Perennial grass production was more responsive to mulch than annual grass productivity. Depending on the site, 300 to $1,200 \mathrm{lbs} /$ acre of mulch is needed in the California annual grassland type to promote infiltration and prevent excessive erosion (Bartolome et al. 1980).

\section{Erosion Control And Other Benefits}

The most serious consequence of overgrazing is loss of the soil profile (Holechek et al. 2001) (Figure 2). Soil formation is a very slow process. A thousand years or more are required to form an inch of soil. However, several inches of soil can be lost from erosion in less than a decade under poorly controlled grazing. The most important part of range management is to maintain enough vegetation residue (mulch) to protect the soil from accelerated erosion.

A variety of studies in several rangeland types reviewed by Branson et al. (1981), Thurow (1991) and Holechek et al. (2001) show soil erosion rates increase as grazing intensities increase and residual vegetation decreases. However light to moderate grazing in-

Table 2. Standing air-dry herbage, mulch, and rate of water intake on heavily, moderately, and lightly grazed watershed in South Dakota.

\begin{tabular}{lccc}
\hline \hline GRAZING & TOTAL & & WATER \\
INTENSITY & HERBAGE & MULCH & INTAKE \\
\hline Heavy & (lb/acre) & (lb/acre) & (in/hr) \\
Moderate & 900 & 456 & 1.05 \\
Light & 1,345 & 399 & 1.69 \\
\hline Source: & 1,869 & 1,100 & 2.95 \\
\hline
\end{tabular}

Source: Data from Rauzi and Hanson 1966. 


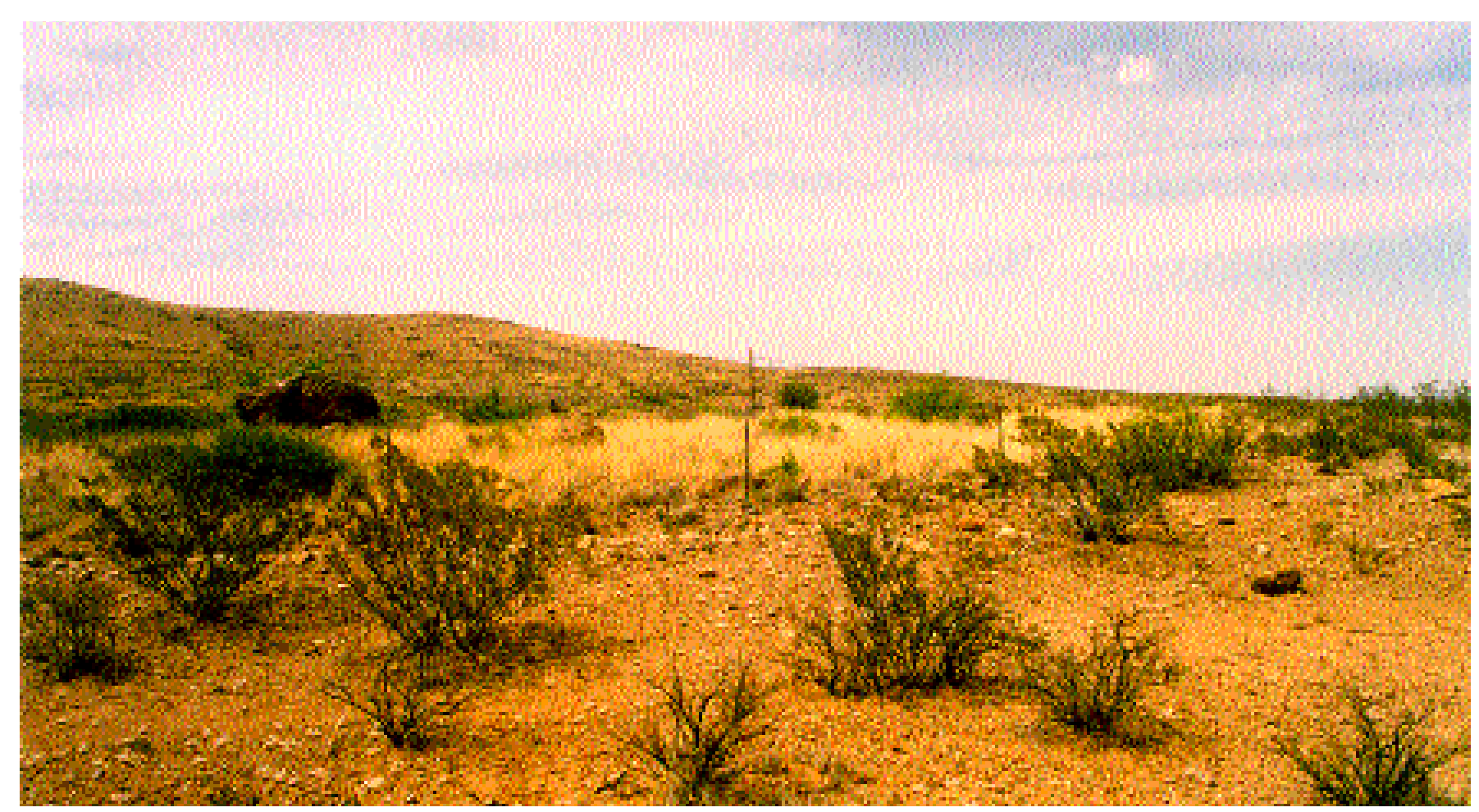

Figure. 2. The heavily grazed pasture in the foreground shows severe erosion due to depletion of vegetation cover. A dense stand of sideoats grama dominates the conservatively grazed pasture in the background. This picture was taken in southwestern New Mexico in winter 1998.

tensity levels generally have resulted in negligible increases in soil erosion over ungrazed controls (Figure 3).

Another apparent benefit: mulch prevents high soil surface temperatures and, thus, retards evaporation

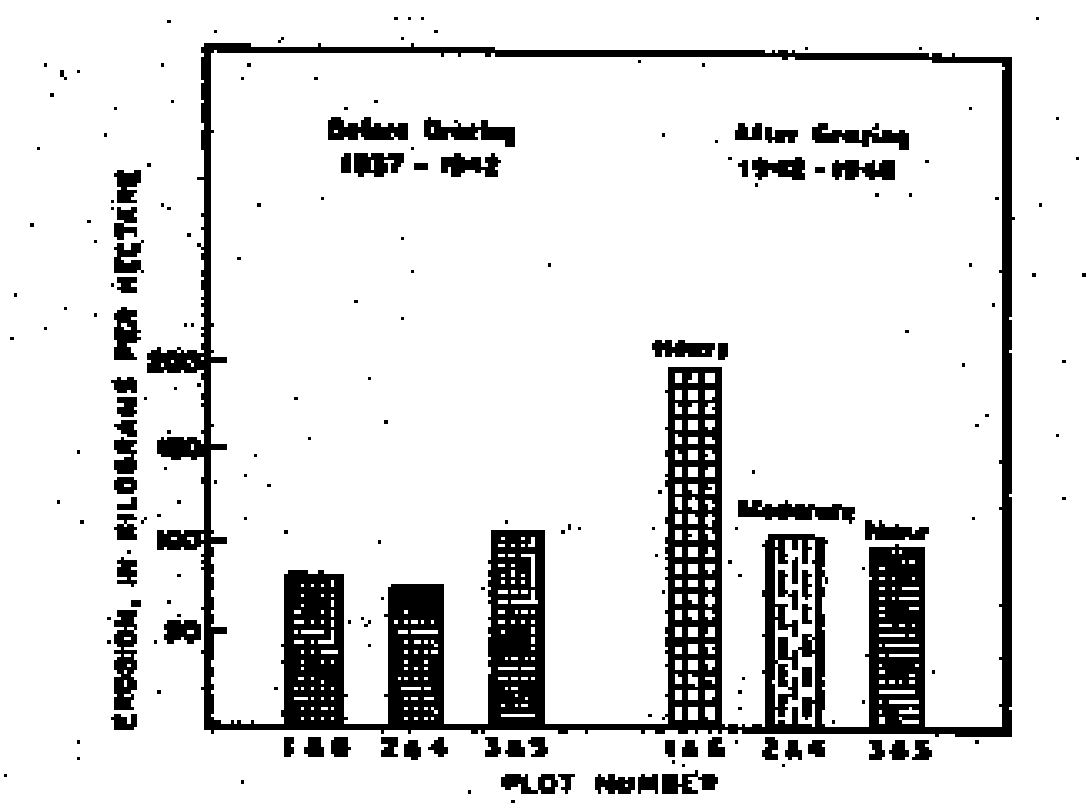

Figure. 3. Average erosion from plots subject to different grazing intensities before grazing (19371942) and after grazing (1942-1948) on pine-bunchgrass range in Colorado. (Adapted from Dunford 1949 by Branson et al. 1981). and improves habitat condition for microbial populations in the soil. Hopkins (1954) found that increasing mulch levels of up to three inches in depth reduced moisture evaporation from Kansas prairie soils by as much

An

In grassland ecosystems mulch can also enhance seed germination and development. It catches seeds, moderates soil temperatures, and increases surface soil moisture (Glendening 1941, Bement et al. 1961). Many range grass seeds are sensitive to wetting and drying during germination. Mulch moderates this effect and, hence, can enhance grass establishment.

\section{Too Much Mulch?}

While lack of mulch-rather than excessive accumulation of mulch - is the problem on arid and semiarid grasslands, on humid grasslands, excessive mulch accumulations can be a challenge. In these areas, excess mulch can retard forage productivity and cause unwanted changes in vegetation composition if controlled burning and grazing are not applied as management tools. 
Several studies from the humid grasslands show removal of some of the mulch by mowing, grazing or burning results in increased yields of green herbage (Vogle 1965, Grelen and Epps 1967). However in the less humid shortgrass and midgrass prairies mulch removal has reduced productivity (Hopkins 1956, Dix 1960). On South Dakota mixed prairie, forage yields varied directly with the level of mulch (Larson and Whitman 1942). Long protected areas produced $43 \%$ more forage than areas where mulch had been removed by mowing.

In the tallgrass prairie, accumulations of mulch on long-term ungrazed areas have delayed spring forage growth, thinned out big bluestem and other tallgrasses, and depressed stand productivity compared to mowed, burned or grazed areas (Dyksterhuis and Schmutz 1947, Weaver and Bruner 1948). This same response has been observed in broomsedge bluestem communities in the southern pine forest (Golley 1965)

On some rangelands excessive mulch accumulations may inhibit growth of desirable species through allelopathy. Allelopathy is the release of toxic plant substances that may be detrimental to other plants. This appears to occur more in woodlands rather than grasslands. (Glendening and Pase 1964, Jameson 1966). Litter from pinyon-juniper, creosotebush, sagebrushes, and chamise has been shown to inhibit germination and growth of understory grasses.

\section{Management For More}

With the exception of the humid grasslands, mulch accumulation basically represents a savings account for ranchers on their rangelands. The more mulch ranchers can accumulate the better they are buffered from climatic adversity in the form of drought.

Several range studies show that in drought periods lightly or conservatively stocked rangelands produced $50 \%$ or more forage than those heavily stocked (Klipple and Costello 1960, Holechek et al. 2000). Moderately stocked rangelands have produced about $20 \%$ more forage than those heavily stocked. Improved moisture infiltration and retention from more mulch appear to largely explain these differences. Therefore, the best insurance policy for a rancher against drought is a good layer of mulch.

Increasingly, grazing intensity guidelines are being based on residual vegetation after grazing. This is because it is now well recognized that rangeland health depends on plant biomass left to protect soil, watershed, wildlife habitat, and aesthetic values.

Research based guides have been developed for the shortgrass prairie (Bement 1969) and California annual grassland (Bartolome et al. 1980). Recently, White and McGinty (1997) have developed residue guidelines for Texas rangelands that should apply well to other parts of the Great Plains. On shortgrass, midgrass and tallgrass rangelands, they recommend minimum residual herbage levels of 300 to 500 , 750 to 1,000 , and 1,200 to 1,500 pounds per acre, respectively. Generally on Chihuahuan and Sonoran Desert rangelands a minimum of 100 to 150 pounds of residue would insure protection on most sites. In the more arid Mojave and salt desert regions, minimum residues of 50 to 100 pounds per acre, depending on the site, seem reasonable. We recommend further research to refine these guidelines.

As a final point, we have found we can easily train most ranchers and range managers to ocularly estimate standing vegetation residue levels to within $35 \mathrm{lbs} /$ acre (dry matter basis). We use both photographs and clipped plots in the field in the training process. Other range scientists have reported most managers could be trained to ocularly estimate standing dry matter to within 25-40 lbs/acre (Smith 1944).

\section{References}

Bartolome, J.W., M.C. Stroud, and H.F. Heady. 1980. Influence of natural mulch on forage production on differing California annual range sites. J. Range Manage. 33:4-8.

Bement, R.E. 1969. A stocking rate guide for beef production on blue grama range. J. Range Manage. 22:83-86.
Bement, R.E., D.F. Hervey, A.C. Everson, and L.O. Hylton, Jr. 1961. Use of asphalt-emulsion mulches to hasten grassseedling establishment. J. Range Manage. 14:102-109.

Bentley, J.R. and M.W. Talbot. 1951. Efficient use of annual plants on cattle ranges in the California foothills. U.S. Dept. Agr. Circ. 870.

Beutner, E.L. and D. Anderson. 1943. The effect of surface mulches on water production on some semidesert grassland soils. J. Amer. Soc. Agron. 33:393-400.

Branson, F.A., G.F. Gifford, K.G. Penfound and R.F. Hadley. 1981. Rangeland hydrology. Range Sciences Series No. 1.

Dix, R.L. 1960. The effects of burning on the mulch structure and species composition of grasslands in western North Dakota. Ecology. 41:49-56.

Dyksterhuis, E.J. and E.M. Schmutz. 1947. Natural mulches of "Litter" of grasslands: with kinds and amounts on a southern prairie. Ecology. 28:163-179.

Dunford, E.G., 1949. Relation of grazing to runoff and erosion on bunchgrass ranges. U.S. Dept. Agr. For. Serv. Nat. RM-7.

Glendening, G.E. 1941. Development of seedlings of Heteropogon cuntortus as related to soil moisture and competition. Bot. Gaz. 102:684-698.

Glendening, G.E. and C.P. Pase. 1964. Effect of litter treatment on germination of species found under manzanita. J. Range Manage. 17:265-266.

Golley, F.B. 1965. Structure and function of an old field broomsedge community. Ecol. Monogr. 35:113-137.

Grelen, H.E. and E.A. Epps, Jr. 1967. Herbage responses to fire and litter removal on southern bluestem range. J. Range Manage. 20:403-404.

Holechek, J.L., M.G. Thomas, D. Galt and F. Molinar. 2000. Conservative and moderate stocking effects on Chihuahuan Desert forage production. Pro. West. Sec. Am. Soc. Anim. Sci. 51:257-260.

Holechek, J.L., R.D. Pieper and C.H. Herbel. 2001. Range Management: principles and practices. $4^{\text {th }}$ Edition. PrenticeHall, Upper Saddle River, NJ

Hopkins, H. 1954. Effects of mulch upon certain factors of the grassland environment. J. Range Manage. 7:255-258.

Hopkins, H. 1956. Effects of mulch on yield and cover in mixed prairie. Trans. Kansas Acad. Sci. 59:71-75.

Jameson, D.A. 1966. Pinyon-juniper litter reduces growth of blue grama. J. Range Manage. 19:214-216.

Johnston, A. 1962. Effects of grazing intensity and cover on the water-intake rate of fescue grassland. J. Range Manage. 15:79-87. 
Klipple, G.E. and D.F. Costello. 1960. Vegetation and cattle responses to different intensities on shortgrass ranges of the central Great Plains. U.S. Dept. Agr. Tech. Bull. 1216.

Kramer, P.J. 1944. Soil moisture in relation to plant growth. Bot. Rev. 10:525-559.

Larson, F. and W. Whitman. 1942. A comparison of used and unused grassland mesas in the badlands of South Dakota. Ecology. 23:438-445.

Launchbaugh, J.L. 1957. The effect of stocking rate on cattle grazing and native shortgrass vegetation in west central Kansas. Kansas Agr. Exp. Sta. Bull. 394.

Rauzi, F. 1960. Water intake studies on range soils at three locations on the northern plains. J. Range Manage. 13:179-184.

Rauzi, F. and C.L. Hanson. 1966. Water and runoff as affected by intensity of grazing. J. Range Manage. 19:351-356.

Rauzi, F. and F.M. Smith. 1973. Infiltration rates: three soils with three grazing levels in northeastern Colorado. J. Range Manage. 26:126-129.
Rhoades, E.D., L.F. Locke, H.M. Taylor and E.H. McIlvain. 1964. Water intake on a sandy range as affected by 20 years of differential cattle stocking rates. J. Range Manage. 17:185-190.

Schwan, H.E., D.J. Hodges and C.N. Weaver. 1949. Influence of grazing and mulch on forage growth. J. Range Manage. 2:142-148.

Sims, P.L., B.E. Dahl and A.H. Denham. 1976. Vegetation and livestock response at three grazing intensities on sandhill rangeland in eastern Colorado. Colorado State Univ. Exp. Sta. Tech. Bull. 130.

Smith, A.D. 1944. A study of the reliability of range vegetation estimates. Ecology. 25:441-448

Smith, D. 1967. Effects of cattle grazing on a ponderosa pine-bunchgrass range in Colorado. U.S. Dept. Agr. For. Serv. Tech. Bull. 1371.

Thurow, T.L. 1991. Hydrology and erosion. In: grazing management. R.H. Hertschmidt and J.W. Stuth, eds. Timber Press, inc., Portland, Ore.
Vogle, R. 1965. Effects of spring burning on yields of brush savanna. J. Range Manage. 18:202-205.

Weaver, J.E. and W.E. Bruner. 1948. Prairies and pastures of the dissected loess plains of central Nebraska. Ecol. Monogr. 18:507-549.

White, L.D. and A. McGinty. 1997. Stocking rate decisions: Key to successful ranching. Texas A \& M Res. Ext. Serv. Publ. 13-5036.

Authors are professors of biology, Center for Biological Studies, University of Juarez, Chihuahua Mexico; private range consultant, 3000 Devendale Drive, Las Cruces, NM 88005 and professor range science, Department of Animal and Range Sciences, New Mexico State University, Las Cruces, NM. This paper was supported by the New Mexico Agricultural Experiment Station and was part of project 1-527417. 